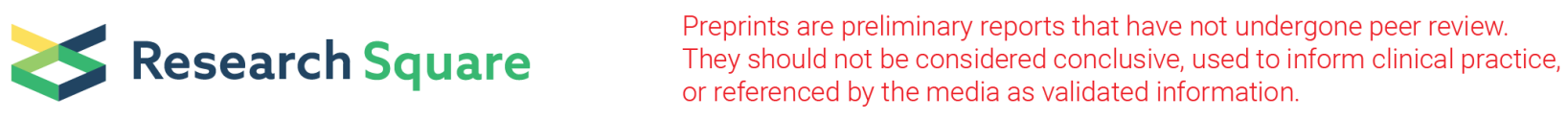

\title{
Predictors of the Demand for Dental Appointments in Primary Health Care: A National Cross-Sectional Study
}

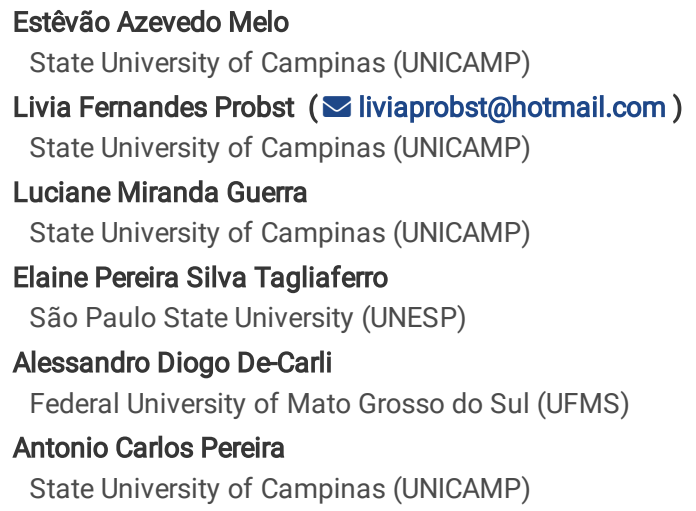




\section{Abstract \\ Background}

Aiming to reverse the current impact of oral diseases, which are among the most prevalent diseases worldwide, it is necessary that public dental services act in an integrated manner within the Health System, particularly with the primary care services. However, even inside availability scenarios in health care, the use of dental services is determined by complex phenomena related to the individual, the environment and practices in which care is offered. The aim of the present study was to evaluate the predictors of the demand for dental care in Primary Health Care Units (PHC) with Oral Health Teams (OHTs).

\section{Methods}

The present is a cross-sectional analytical study that used data from the external assessment of the third cycle of the National Program for Improving Access and Quality in Primary Care (PMAQ-AB, Programa Nacional de Melhoria do Acesso e da Qualidade da Atenção Básica), carried out between 2017 and 2018 , in Brazil. The final sample consisted of 85,231 patients and 22,475 Oral Health teams (OHTs). The outcome variable was the fact that the user requested a dental appointment at the Health Unit. A multilevel analysis was carried out to verify the association between individual variables (related to users) and contextual variables (related to the OHTs) in relation to the outcome.

\section{Results}

In the final model, of the variables at the individual level, the patient's age over 43 years $(\mathrm{OR}=2.03,95 \% \mathrm{Cl}$ : $1.96-2.10)$ was the one that had the greatest effect on the outcome. In turn, among the contextual variables related to the teams, the ones with the greatest effect on the outcome were 'oral health teams that assisted no more than a single family health team' (OR $=1.29,95 \% \mathrm{Cl}: 1.23-1.36)$ or 'those in which the dental form constitutes the user's medical record' (OR $=1.21,95 \% \mathrm{Cl}$ : 1.15-1.26) were predictors of the demand for a dental appointment in Primary Health Care.

\section{Conclusion}

It can be concluded that individual and contextual issues interfere in the demand for dental care. Oral health planning must consider an active search for patients with profiles that do not favor the spontaneous demand for oral health care, such as being older, male gender and non-white ethnicity. It is also concluded that the oral health teams that worked in line with the Brasil Sorridente guidelines are the teams most often sought after by the users.

\section{Background}

The acknowledgment that health is a basic human right implies the guarantee of universal access to Primary Health Care (PHC) services, including actions of health promotion, prevention, treatment, rehabilitation and palliative care.[1, 2] Identified by the World Health Organization Health (WHO) as a strategic priority, the universality of access is one of the principles of the Brazilian Unified Health System (SUS, Sistema Único de Saúde), which has characteristics that differentiate its organization system from that of other models proposed in several countries.[2, 3] Among these, the role of a multiprofessional team responsible for certain geographic territories and the registered population stands out, as well as the presence of community health agents (CHAs) and the inclusion of comprehensive oral health care in the public health system.[4, 5]

In the oral health field, SUS has produced important changes in health care. The National Oral Health Policy (PNSB, Política Nacional de Saúde Bucal), instituted in 2004 as part of the national health strategies, was able to expand the population coverage by the Oral Health teams (OHTs) by more than $378 \%$, which increased from $9 \%$ in 2002, the period PNSB pre-implantation, to $43 \%$ in 2016, 12 years after its implementation.[6-8] However, there is still a shortage of professionals in dental care, which has an impact on access to care, particularly by the population in the more vulnerable social strata,[6] as well as the fact that political and economic variables after 2016 may have changed this progress.

In this context, it is necessary to consider that oral diseases are among the most prevalent ones worldwide and, although they are largely preventable, public oral health policies remain inadequately funded for disease prevention and treatment.[9] To reverse this situation, it is necessary for dental services to act in an integrated manner within the Health Care System, particularly with primary health services.[7, 8] However, even in scenarios with guaranteed and subsidized care, the use of dental services can be influenced by issues related to the individual, such as overall awareness of oral health or a previous negative experience.[10]

In addition to individual issues, the use of available health services is determined by complex interactions with the environment and with the practices in which care is offered.[11] Therefore, it can be affirmed that the oral health status of a population is influenced by the values and attitudes of the people and communities and reflects the physiological, social and psychological attributes that are essential for the individual's physical and mental well-being.[12 ]

However, there is a knowledge gap regarding the combination of individual and contextual variables that favor or hinder the demand and use of the offered services. Identifying and analyzing these issues is crucial to support the planning and management of dental services, favoring the population's oral health promotion. Given the abovementioned facts, the aim of the present study was to evaluate the predictors of demand for dental care in PHC Units with an OHT.

\section{Methods}




\section{Study design and context}

The present is a cross-sectional analytical study reported according to the STrengthening the Reporting of OBservational studies in Epidemiology (STROBE) statement.[13] Our study uses data from the external assessment of the third cycle of the National Program for Improving Access and Quality in Primary Care (PMAQ-AB), carried out between 2017 and 2018, in Brazil. The PMAQ-AB corresponds to the set of actions that investigated the access and quality conditions of all participating municipalities and primary care teams.[14]

\section{Participants}

Microdata obtained from interviews with users and professionals of the Oral Health team from Basic Health Units (BHUs) across the country were used in this study, totaling a final sample of 85,231 patients and 22,475 Oral Health teams.

\section{Analyzed variables}

The analyzed variables are presented below, as well as how the qualitative and quantitative variables were treated in the analysis. The supplementary material depicts a detailed presentation of the PMAQ-AB, the used interview instruments, the collection of data, and the choice of the variables that were included in this study.

\section{Outcome variable}

To have sought dental appointments at the Health Unit.

Individual independent variables (of patients):

- Gender: male or female.

- Age: in full years.

- Marital status: single, married or in a common-law marriage, divorced, or legally separated, widowed.

- Self-declared ethnicity: white, black, yellow, brown/mixed-race or indigenous.

- Education: illiterate, literate, incomplete elementary school, complete elementary school, incomplete high school, complete high school, incomplete higher education, complete higher education, postgraduate.

- Family income: Total amount in Reais (R\$).

- Residents in the household: in numbers.

\section{Contextual independent variables (of the Oral Health teams- OHTs):}

- Total family health teams (FHTs) assisted by an OHT: Number of assisted teams.

- Frequency at which the OHT attends to users outside the coverage area: Every day, some days of the week, never.

- The OHT has a territory map: Yes or No.

- The OHT plans its actions: Yes or No.

- The OHT participates in meetings together with the FHT: Yes or No.

- The OHT investigates the epidemiological profile of the population from the territory: Yes or No.

- The OHT discusses cases and therapeutic projects: Yes or No.

- The OHT performs a self-assessment process: Yes or No.

- Self-assessment instrument used: printed Self-assessment for the Improvement of Access and Quality of Primary Care (AMAQ, Auto-Avaliação para a Melhoria do Acesso e da Qualidade da Atenção Básica), electronic AMAQ; Quality Improvement Assessment (AMQ, Avaliação para Melhoria da Qualidade); Instrument developed by the municipality / team; Instrument developed by the State; another assessment tool.

- Clinical dental file comprises the user's medical record: Yes or No.

- The OHT performs actions that are articulated with other social facilities in the territory: Yes or No.

- The OHT performs scheduled care service: Yes or No.

- The OHT performs spontaneous demand care service: Yes or No.

- The OHT performs user embracement jointly with the Primary Care team: Yes or No.

- Main form of scheduling the 1st dental appointment: at the Unit reception (together with the scheduling for the other professionals), at the dental office (by the oral health team), by the Community Health Agent (ACS), others.

\section{Statistical methods}

Initially, the descriptive analyses of individual and contextual variables were performed. For that purpose, absolute and relative frequencies were used for categorical variables, whereas mean, standard deviation, median, minimum and maximum values were used for quantitative variables.

Subsequently, analyses of the associations between the outcome (having sought dental appointments at the Health Unit) and individual and contextual variables were performed, using simple and multiple multilevel logistic regression models. The variables in the first level (individual, patients) and in the second level (contextual, Oral Health teams) were considered in the model. 
The variables that showed $p<0.20$ in the crude analyses were studied in the multiple models. Initially, the first-level variables were included in the model, and those with $p \leq 0.05$ remained after adjustments for the first-level variables. Subsequently, the second-level variables were included, and those with $p \leq 0.05$ after the adjustments for the other variables remained in the final model. The gross odds ratio (OR) was estimated by the regression models and adjusted with the $95 \%$ confidence intervals. The adjustment of the models was evaluated by the QIC (Quasi-likelihood Criterion). The analyses were performed using the software R.[15]

\section{Ethical aspects}

The project was approved by the Ethics Committee for Research with Human Beings (CAAE n. 80477417.0.0000.0021). The microdata were obtained through public and unrestricted access on June 25, 2019.

\section{Results}

The data of 85,231 patients of 22,475 Oral Health teams were analyzed. Table 1 shows the results of the descriptive analyses of the variables at the individual level (patients). It can be observed that only $58.1 \%$ of the patients registered in the units with an oral health team had already sought dental appointments. The mean age of patients in the sample is 43.8 years, ranging from 18 to 99 years, with $78.5 \%$ of females and $63.4 \%$ married or in a common-law marriage.

Table 1

Descriptive analysis of the participants' variables (individual), $\mathrm{n}=85,231$ participants, Brazil 2017.

\begin{tabular}{|c|c|c|}
\hline Variable & Category & Frequency (\%) \\
\hline \multirow[t]{2}{*}{ Sought dental care (outcome) } & Yes & $49500(58.1 \%)$ \\
\hline & No & $35731(41.9 \%)$ \\
\hline \multirow[t]{2}{*}{ Gender } & Male & $18360(21.5 \%)$ \\
\hline & Female & $66871(78.5 \%)$ \\
\hline \multirow[t]{4}{*}{ Marital status } & Single & $19655(23.1 \%)$ \\
\hline & Married or in a common-law marriage & $54009(63.4 \%)$ \\
\hline & Divorced/Separated & $5677(6.7 \%)$ \\
\hline & Widowed & $5890(6.9 \%)$ \\
\hline \multirow[t]{6}{*}{ Self-declared ethnicity } & White & $25645(30.1 \%)$ \\
\hline & Black & $10857(12.7 \%)$ \\
\hline & Yellow & $2610(3.1 \%)$ \\
\hline & Brown/Mixed-race & $44227(51.9 \%)$ \\
\hline & Indigenous & $753(0.9 \%)$ \\
\hline & No information & $1139(1.3 \%)$ \\
\hline \multirow[t]{11}{*}{ Level of schooling } & Illiterate & $4818(5.7 \%)$ \\
\hline & Literate & $4525(5.3 \%)$ \\
\hline & Incomplete Elementary School & $27808(32.6 \%)$ \\
\hline & Complete Elementary School & $8634(10.1 \%)$ \\
\hline & Incomplete High School & $8839(10.4 \%)$ \\
\hline & Complete High School & $22755(26.7 \%)$ \\
\hline & Incomplete Higher Education & $2977(3.5 \%)$ \\
\hline & Complete Higher Education & $3894(4.6 \%)$ \\
\hline & Postgraduate Education & $858(1.0 \%)$ \\
\hline & No information & $123(0.1 \%)$ \\
\hline & Mean (standard deviation) & Median (minimum and maximum value) \\
\hline Age & $43.74(16.31)$ & $42.0(18.0 ; 99.0)$ \\
\hline Income & $1585.58(2854.39)$ & $980.0(1.0 ; 98.500 .0)$ \\
\hline Number of people in the family & $3.60(1.66)$ & $3.0(1.0 ; 30.0)$ \\
\hline
\end{tabular}

Table 2 shows the descriptive analyses of the teams' variables. It can be observed that, on average, the teams provide assistance to a mean of 1.2 Family Health teams and $92.8 \%$ of the teams attend to people living outside their area of coverage on at least some days of the week. The Self-assessment for the 
Improvement of Access and Quality of Primary Care (AMAQ) instrument, either in its printed or electronic form, is the main instrument used in the selfassessment process (77.1\%). As for the scheduling of patients, this process is carried out at the reception of the Basic Health Unit (UBS) only for $29.3 \%$ of the teams, together with the scheduling for the other professionals' services. Likewise, the clinical dental record is integrated to the user's medical record in only $76.9 \%$ of cases.

It is also observed that $79.9 \%$ of the teams participate in meetings together with the Primary Care team, but only $47.7 \%$ carry out the discussion of cases and therapeutic projects. The epidemiological profile of the assisted population is investigated by $55.3 \%$ of the interviewed teams. In turn, most teams ( $91.5 \%$ )

carry out actions that are integrated with other social facilities in the territory and user embracement is performed jointly with the Primary Care team (83.1\%). 
Table 2

Descriptive analysis of contextual variables (Oral Health Teams) $n=22,475$ Teams, Brazil 2017.

\begin{tabular}{|c|c|c|}
\hline Variable & Category & Frequency (\%) \\
\hline \multirow[t]{3}{*}{ Frequency at which the OHT team attends to users outside the coverage area } & Everyday & $10971(48.8 \%)$ \\
\hline & Some days of the week & $9884(44.0 \%)$ \\
\hline & Never & $1620(7.2 \%)$ \\
\hline \multirow[t]{2}{*}{ The OHT has a territory map } & Yes & $18835(83.8 \%)$ \\
\hline & No & $3640(16.2 \%)$ \\
\hline \multirow[t]{2}{*}{ The OHT plans their actions } & Yes & $15111(67.2 \%)$ \\
\hline & No & $7364(32.8 \%)$ \\
\hline \multirow[t]{2}{*}{ The OHT participates in joint meetings with the FHTs } & Yes & $17957(79.9 \%)$ \\
\hline & No & $4518(20.1 \%)$ \\
\hline \multirow[t]{2}{*}{ The $\mathrm{OHT}$ investigates the epidemiological profile of the territory population } & Yes & $12436(55.3 \%)$ \\
\hline & No & $10039(44.7 \%)$ \\
\hline \multirow[t]{2}{*}{ The OHT discusses cases and therapeutic projects } & Yes & $10710(47.7 \%)$ \\
\hline & No & $11765(52.3 \%)$ \\
\hline \multirow[t]{2}{*}{ The OHT performs the self-assessment process } & Yes & $18175(80.9 \%)$ \\
\hline & No & $4300(19.1 \%)$ \\
\hline \multirow[t]{7}{*}{ Self-assessment instrument used } & Printed AMAQ & $11277(50.2 \%)$ \\
\hline & Electronic AMAQ & $6045(26.9 \%)$ \\
\hline & AMQ & $105(0.5 \%)$ \\
\hline & Municipality Instrument & $396(1.8 \%)$ \\
\hline & State Instrument & $73(0.3 \%)$ \\
\hline & Other instruments & $279(1.2 \%)$ \\
\hline & Not applicable & $4300(19.1 \%)$ \\
\hline \multirow[t]{2}{*}{ The clinical dental file is integrated with the user's medical record } & Yes & $17277(76.9 \%)$ \\
\hline & No & $5198(23.1 \%)$ \\
\hline \multirow[t]{2}{*}{ The $\mathrm{OHT}$ performs actions articulated with other social facilities in the territory } & Yes & $20570(91.5 \%)$ \\
\hline & No & $1905(8.5 \%)$ \\
\hline \multirow[t]{2}{*}{ The OHT performs scheduled service } & Yes & $22036(98.0 \%)$ \\
\hline & No & $439(2.0 \%)$ \\
\hline \multirow[t]{2}{*}{ The OHT performs spontaneous demand service } & Yes & $22040(98.1 \%)$ \\
\hline & No & $435(1.9 \%)$ \\
\hline \multirow[t]{3}{*}{ The OHT performs user embracement jointly with the FHT } & Yes & $18674(83.1 \%)$ \\
\hline & No & $3714(16.5 \%)$ \\
\hline & Not applicable & $87(0.4 \%)$ \\
\hline \multirow[t]{4}{*}{ Main type of scheduling the 1 st dental appointment } & At the $\mathrm{BHU}$ reception & $6585(29.3 \%)$ \\
\hline & At the dental office & $11661(51.9 \%)$ \\
\hline & Through CHAs & $3868(17.2 \%)$ \\
\hline & Another type & $361(1.6 \%)$ \\
\hline Variable & Mean (standard deviation) & Median (minimum and maximum value) \\
\hline Number of assisted OHTs & $1.22(0.67)$ & $1.0(1.0 ; 9.0)$ \\
\hline
\end{tabular}

In the crude analyses, where each variable was analyzed individually, all variables showed a significant association with the outcome "having sought dental care with the dentist in this health unit" $(p<0.05)$. In the final model, that is, after the adjustments between the variables, the patient's variables were significantly associated with the outcome: gender, age, ethnicity/skin color, level of schooling, income and number of people in the family, as well as the OHT 
variables: number of FHTs to which the OHTs provide assistance, frequency with which it attends to users outside the coverage area, whether it participates in meetings together with the $\mathrm{FHT}$, if it investigates the epidemiological profile of the territory population, if there is a discussion of cases and therapeutic projects, if the clinical dental file is part of the user's medical record, if the OHT carries out actions with other social facilities in the territory and if the OHT professionals carry out user embracement together with the FHT $(p<0.05)($ Table 3$)$. 
Table 3

Results of the logistic regression models for the outcome "having sought dental care at this health unit" ( $\mathrm{n}=85,231$ participants from 22,475 teams), Brazil, :

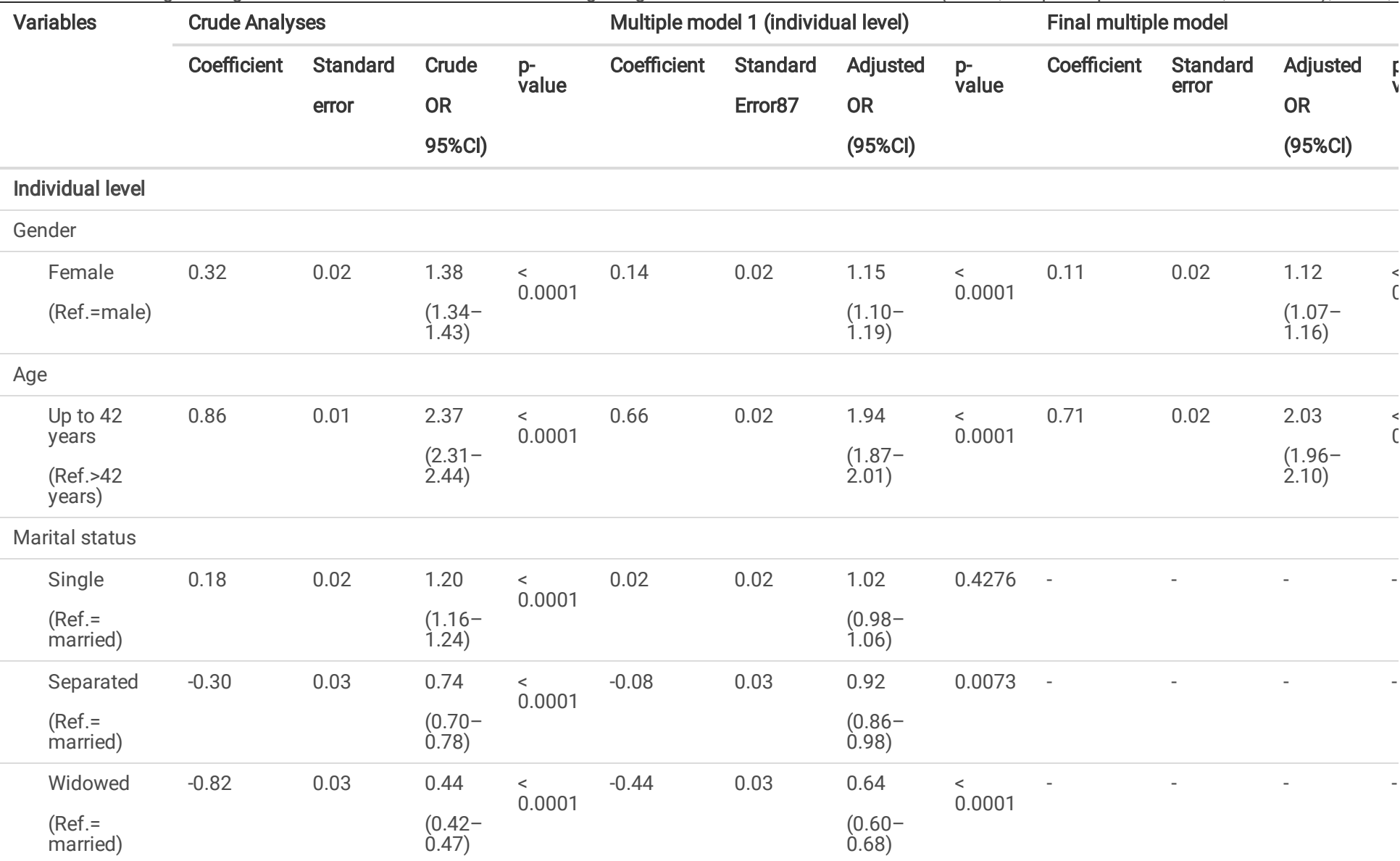

Self-declared

ethnicity

\begin{tabular}{|c|c|c|c|c|c|c|c|c|c|c|c|c|}
\hline $\begin{array}{l}\text { Black } \\
\text { (Ref.=white) }\end{array}$ & 0.20 & 0.02 & $\begin{array}{l}1.23 \\
(1.17- \\
1.29)\end{array}$ & $\begin{array}{l}<.0001 \\
0.001\end{array}$ & 0.08 & 0.03 & $\begin{array}{l}1.08 \\
(1.02- \\
1.14)\end{array}$ & 0.0042 & 0.12 & 0.03 & $\begin{array}{l}1.12 \\
(1.07- \\
1.19)\end{array}$ & $\hat{c}$ \\
\hline $\begin{array}{l}\text { Yellow } \\
\text { (Ref.=white) }\end{array}$ & 0.22 & 0.04 & $\begin{array}{l}1.25 \\
(1.15- \\
1.36)\end{array}$ & $\begin{array}{l}< \\
0.0001\end{array}$ & 0.02 & 0.05 & $\begin{array}{l}1.02 \\
(0.93- \\
1.12)\end{array}$ & 0.6385 & 0.03 & 0.05 & $\begin{array}{l}1.03 \\
(0.94- \\
1.13)\end{array}$ & C \\
\hline $\begin{array}{l}\text { Brown } \\
\text { (Ref.=white) }\end{array}$ & 0.25 & 0.02 & $\begin{array}{l}1.29 \\
(1.25- \\
1.33)\end{array}$ & $\begin{array}{l}< \\
0.0001\end{array}$ & 0.08 & 0.02 & $\begin{array}{l}1.08 \\
(1.05- \\
1.12)\end{array}$ & $\begin{array}{l}< \\
0.0001\end{array}$ & 0.09 & 0.02 & $\begin{array}{l}1.10 \\
(1.06- \\
1.14)\end{array}$ & $\hat{c}$ \\
\hline $\begin{array}{l}\text { Indigenous } \\
\text { (Ref.=white) }\end{array}$ & 0.33 & 0.08 & $\begin{array}{l}1.39 \\
(1.20- \\
1.61)\end{array}$ & $\begin{array}{l}< \\
0.0001\end{array}$ & 0.14 & 0.09 & $\begin{array}{l}1.15 \\
(0.97- \\
1.36)\end{array}$ & 0.1146 & 0.19 & 0.09 & $\begin{array}{l}1.21 \\
(1.02- \\
1.44)\end{array}$ & C \\
\hline $\begin{array}{l}\text { Level of } \\
\text { schooling } \\
\text { (Ref. Complete } \\
\text { Elementary } \\
\text { School) }\end{array}$ & 0,37 & 0.01 & $\begin{array}{l}1.44 \\
(1.40- \\
1.48)\end{array}$ & $\begin{array}{l}<.0001 \\
0.00\end{array}$ & 0.10 & 0.02 & $\begin{array}{l}1.10 \\
(1.06- \\
1.14)\end{array}$ & $\begin{array}{l}<.0001 \\
0.00\end{array}$ & 0.11 & 0.02 & $\begin{array}{l}1.12 \\
(1.08- \\
1.16)\end{array}$ & i \\
\hline $\begin{array}{l}\text { Renda familiar } \\
\text { (Ref.>R\$980) }\end{array}$ & 0,32 & 0.02 & $\begin{array}{l}1.37 \\
(1.33- \\
1.42)\end{array}$ & $\begin{array}{l}< \\
0.0001\end{array}$ & 0.27 & 0.02 & $\begin{array}{l}1.30 \\
(1.27- \\
1.35)\end{array}$ & $\begin{array}{l}<.0001 \\
0.000\end{array}$ & 0.24 & 0.02 & $\begin{array}{l}1.27 \\
(1.23- \\
1.31)\end{array}$ & í \\
\hline $\begin{array}{l}\text { People in the } \\
\text { family } \\
\text { (Ref. } \leq 3 \text { ) }\end{array}$ & 0,46 & 0.01 & $\begin{array}{l}1.58 \\
(1.54- \\
1.63)\end{array}$ & $\begin{array}{l}< \\
0.0001\end{array}$ & 0.30 & 0.02 & $\begin{array}{l}1.35 \\
(1.31- \\
1.40)\end{array}$ & $\begin{array}{l}<.0001 \\
0.000\end{array}$ & 0.33 & 0.02 & $\begin{array}{l}1.39 \\
(1.35- \\
1.44)\end{array}$ & i \\
\hline
\end{tabular}

Contextual level (Teams)

QIC: Quasi-likelihood Criterion (empty model): 115.923,22. OR = Odds ratio; Cl = de confidence interval 


\begin{tabular}{|c|c|c|c|c|c|c|c|c|c|c|c|c|}
\hline \multirow[t]{2}{*}{ Variables } & \multicolumn{4}{|c|}{ Crude Analyses } & \multicolumn{4}{|c|}{ Multiple model 1 (individual level) } & \multicolumn{4}{|c|}{ Final multiple model } \\
\hline & Coefficient & $\begin{array}{l}\text { Standard } \\
\text { error }\end{array}$ & $\begin{array}{l}\text { Crude } \\
\text { OR } \\
95 \% \mathrm{Cl})\end{array}$ & $\begin{array}{l}\mathrm{p}- \\
\text { value }\end{array}$ & Coefficient & $\begin{array}{l}\text { Standard } \\
\text { Error87 }\end{array}$ & $\begin{array}{l}\text { Adjusted } \\
\text { OR } \\
(95 \% \mathrm{Cl})\end{array}$ & $\begin{array}{l}\text { p- } \\
\text { value }\end{array}$ & Coefficient & $\begin{array}{l}\text { Standard } \\
\text { error }\end{array}$ & $\begin{array}{l}\text { Adjusted } \\
\text { OR } \\
(95 \% \mathrm{Cl})\end{array}$ & i \\
\hline $\begin{array}{l}\text { Number of } \\
\text { assisted FHTs } \\
\text { (Ref. >1) }\end{array}$ & 0.34 & 0.02 & $\begin{array}{l}1.40 \\
(1.36- \\
1.46)\end{array}$ & $\dot{e} 0001$ & - & - & - & - & 0.25 & 0.03 & $\begin{array}{l}1.29 \\
(1.23- \\
1.36)\end{array}$ & $\hat{c}$ \\
\hline $\begin{array}{l}\text { Frequency at } \\
\text { which the } \mathrm{OHT} \\
\text { attends to users } \\
\text { outside the area }\end{array}$ & & & & & & & & & & & & \\
\hline $\begin{array}{l}\text { Some days } \\
\text { (Ref.=daily) }\end{array}$ & 0.08 & 0.01 & $\begin{array}{l}1.09 \\
(1.06- \\
1.12)\end{array}$ & $e_{0.0001}$ & - & - & - & - & 0.07 & 0.02 & $\begin{array}{l}1.07 \\
(1.03- \\
1.11)\end{array}$ & $c$ \\
\hline $\begin{array}{l}\text { Never } \\
\text { (Ref.=daily) }\end{array}$ & 0.06 & 0.03 & $\begin{array}{l}1.06 \\
(1.00- \\
1.12)\end{array}$ & 0.0412 & - & - & - & - & 0.10 & 0.04 & $\begin{array}{l}1.11 \\
(1.03- \\
1.19)\end{array}$ & $c$ \\
\hline $\begin{array}{l}\text { Territory map } \\
\text { (Ref.=no) }\end{array}$ & 0.19 & 0.02 & $\begin{array}{l}1.21 \\
(1.16- \\
1.25)\end{array}$ & $\dot{0}_{0.0001}$ & - & - & - & - & - & - & - & - \\
\hline $\begin{array}{l}\text { Planning of } \\
\text { actions } \\
\text { (Ref.=no) }\end{array}$ & 0.16 & 0.01 & $\begin{array}{l}1.17 \\
(1.14- \\
1.20)\end{array}$ & $\dot{0}_{0.0001}$ & - & - & - & - & - & - & - & - \\
\hline $\begin{array}{l}\text { Meetings } \\
\text { together with } \\
\text { the FHT } \\
\text { (Ref.=no) }\end{array}$ & 0.25 & 0.02 & $\begin{array}{l}1.28 \\
(1.24- \\
1.32)\end{array}$ & $\dot{0}_{0.0001}$ & - & - & - & - & 0.12 & 0.02 & $\begin{array}{l}1.13 \\
(1.08- \\
1.19)\end{array}$ & ¿ \\
\hline $\begin{array}{l}\text { Investigation of } \\
\text { the } \\
\text { epidemiological } \\
\text { profile } \\
\text { (Ref.=no) }\end{array}$ & 0.19 & 0.01 & $\begin{array}{l}1.21 \\
(1.18- \\
1.24)\end{array}$ & $\dot{0}_{0.0001}$ & - & - & - & - & 0.11 & 0.02 & $\begin{array}{l}1.12 \\
(1.07- \\
1.16)\end{array}$ & ¿ \\
\hline $\begin{array}{l}\text { Disses cases } \\
\text { and therapeutic } \\
\text { projects } \\
\text { (Ref.=no) }\end{array}$ & 0.15 & 0.01 & $\begin{array}{l}1.16 \\
(1.13- \\
1.19)\end{array}$ & $\overleftarrow{0} .0001$ & - & - & - & - & 0.08 & 0.02 & $\begin{array}{l}1.08 \\
(1.04- \\
1.13)\end{array}$ & c \\
\hline $\begin{array}{l}\text { Self-evaluation } \\
\text { process } \\
\text { (Ref.=no) }\end{array}$ & 0.18 & 0.02 & $\begin{array}{l}1.20 \\
(1.16- \\
1.25)\end{array}$ & $\hat{0} .0001$ & - & - & - & - & - & - & - & - \\
\hline Instrument used & & & & & & & & & & & & \\
\hline $\begin{array}{l}\text { Printed } \\
\text { AMAQ } \\
\text { (Ref.= } \\
\text { electronic } \\
\text { AMAQ) }\end{array}$ & 0.10 & 0.02 & $\begin{array}{l}1.11 \\
(1.07- \\
1.14)\end{array}$ & $\hat{0} .0001$ & - & - & - & - & - & - & - & - \\
\hline $\begin{array}{l}\text { AMQ } \\
\text { (Ref.= } \\
\text { electronic } \\
\text { AMAQ) }\end{array}$ & -0.00 & 0.10 & $\begin{array}{l}1.00 \\
(0.82- \\
1.22)\end{array}$ & 0.9963 & - & - & - & - & - & - & - & - \\
\hline $\begin{array}{l}\text { Municipality } \\
\text { instrument } \\
\text { (Ref.= } \\
\text { electronic } \\
\text { AMAQ) }\end{array}$ & -0.12 & 0.05 & $\begin{array}{l}0.89 \\
(0.80- \\
0.98)\end{array}$ & 0.0257 & - & - & - & - & - & - & - & - \\
\hline
\end{tabular}




\begin{tabular}{|c|c|c|c|c|c|c|c|c|c|c|c|c|}
\hline \multirow[t]{2}{*}{ Variables } & \multicolumn{4}{|c|}{ Crude Analyses } & \multicolumn{4}{|c|}{ Multiple model 1 (individual level) } & \multicolumn{4}{|c|}{ Final multiple model } \\
\hline & Coefficient & $\begin{array}{l}\text { Standard } \\
\text { error }\end{array}$ & $\begin{array}{l}\text { Crude } \\
\text { OR } \\
95 \% \mathrm{Cl})\end{array}$ & $\begin{array}{l}\mathrm{p}- \\
\text { value }\end{array}$ & Coefficient & $\begin{array}{l}\text { Standard } \\
\text { Error87 }\end{array}$ & $\begin{array}{l}\text { Adjusted } \\
\text { OR } \\
(95 \% \mathrm{Cl})\end{array}$ & $\begin{array}{l}\mathrm{p}- \\
\text { value }\end{array}$ & Coefficient & $\begin{array}{l}\text { Standard } \\
\text { error }\end{array}$ & $\begin{array}{l}\text { Adjusted } \\
\text { OR } \\
(95 \% \mathrm{Cl})\end{array}$ & \\
\hline $\begin{array}{l}\text { State } \\
\text { instrument } \\
\text { (Ref.= } \\
\text { electronic } \\
\text { AMAQ) }\end{array}$ & -0.24 & 0.12 & $\begin{array}{l}0.79 \\
(0.62- \\
1.00)\end{array}$ & 0.0538 & - & - & - & - & - & - & - & - \\
\hline $\begin{array}{l}\text { Another } \\
\text { instrument } \\
\\
\text { (Ref.= } \\
\text { electronic } \\
\text { AMAQ) }\end{array}$ & -0.08 & 0.06 & $\begin{array}{l}0.93 \\
(0.82- \\
1.05)\end{array}$ & 0.2283 & - & - & - & - & - & - & - & - \\
\hline $\begin{array}{l}\text { Clinical dental } \\
\text { file integrated } \\
\text { with medical } \\
\text { record } \\
\text { (Ref.=no) }\end{array}$ & 0,26 & 0.02 & $\begin{array}{l}1.29 \\
(1.25- \\
1.33)\end{array}$ & $\begin{array}{l}< \\
0.0001\end{array}$ & - & - & - & - & 0.19 & 0.02 & $\begin{array}{l}1.21 \\
(1.15- \\
1.26)\end{array}$ & \\
\hline $\begin{array}{l}\text { Articulated } \\
\text { actions } \\
\text { (Ref.=no) }\end{array}$ & 0,21 & 0.02 & $\begin{array}{l}1.23 \\
(1.17- \\
1.29)\end{array}$ & $\begin{array}{l}< \\
0.0001\end{array}$ & - & - & - & - & 0.09 & 0.03 & $\begin{array}{l}1.10 \\
(1.03- \\
1.18)\end{array}$ & $c$ \\
\hline $\begin{array}{l}\text { Programmed } \\
\text { care } \\
\text { (Ref.=no) }\end{array}$ & 0,16 & 0.05 & $\begin{array}{l}1.17 \\
(1.06- \\
1.29)\end{array}$ & 0.0013 & - & - & - & - & - & - & - & - \\
\hline $\begin{array}{l}\text { Attends to } \\
\text { spontaneous } \\
\text { demand } \\
\text { (Ref.=no) }\end{array}$ & 0,15 & 0.05 & $\begin{array}{l}1.16 \\
(1.05- \\
1.28)\end{array}$ & 0.0033 & - & - & - & - & - & - & - & - \\
\hline $\begin{array}{l}\text { Joint user } \\
\text { embracement } \\
\text { (Ref.=no) }\end{array}$ & 0,28 & 0.02 & $\begin{array}{l}1.32 \\
(1.27- \\
1.37)\end{array}$ & $<.0001$ & - & - & - & - & 0.14 & 0.02 & $\begin{array}{l}1.15 \\
(1.10- \\
1.21)\end{array}$ & \\
\hline Scheduling & & & & & & & & & & & & \\
\hline $\begin{array}{l}\text { At the } \\
\text { reception } \\
\text { (Ref.=at the } \\
\text { office) }\end{array}$ & 0,13 & 0,02 & $\begin{array}{l}1,14 \\
(1,11- \\
1,18)\end{array}$ & $\begin{array}{l}<, 0001 \\
0,0\end{array}$ & - & - & - & - & - & - & - & - \\
\hline $\begin{array}{l}\text { Through the } \\
\text { CHA } \\
\text { (Ref.=at the } \\
\text { office) }\end{array}$ & 0,25 & 0,02 & $\begin{array}{l}1,28 \\
(1,23- \\
1,33)\end{array}$ & $\begin{array}{l}<, 0001 \\
0,\end{array}$ & - & - & - & - & - & - & - & - \\
\hline $\begin{array}{l}\text { Another } \\
\text { type } \\
\text { (Ref.=at the } \\
\text { office) }\end{array}$ & $-0,20$ & 0,05 & $\begin{array}{l}0,82 \\
(0,74- \\
0,91)\end{array}$ & 0,0003 & - & - & - & - & - & - & - & - \\
\hline $\begin{array}{l}\text { Akaike } \\
\text { Information } \\
\text { Criterion } \\
\text { (AICc) }\end{array}$ & & & & & & & & & $90.952,17$ & & 90.146 .69 & \\
\hline
\end{tabular}

The chance of seeking dental care from the dentist at the Health Unit is significantly higher among women, younger patients, patients of black, brown, and indigenous ethnicity compared to white patients, and among patients with a higher level of education, with lower income and larger families.

In turn, the demand for dental appointments is significantly higher in the teams that attend to a single FHT, in those with a lower frequency of care provided to people living outside the coverage area, who participate in meetings together with the FHT, which investigate the epidemiological profile of the assisted population, who discuss cases and therapeutic projects, in which the clinical dental file is included in the user's medical record, which performs actions articulated with other social facilities in the territory and which perform user embracement together with the Primary Care team. 
Among the variables of the individual level, the patient's age $(\mathrm{OR}=2.03,95 \% \mathrm{Cl}: 1.96-2.10)$ was the one with the greatest effect on the outcome, whereas among the teams' variables, working with only one Primary Care team $(\mathrm{OR}=1.29,95 \% \mathrm{Cl}: 1.23-1.36)$ and having the clinical dental file included in the user's medical record $(\mathrm{OR}=1.21,95 \% \mathrm{Cl}: 1.15-1.26)$ were the variables with the greatest effect.

\section{Discussion}

With a pioneering and bold approach in comparison with other public health systems worldwide, Brazil offers its citizens universal oral health care services, from prevention to rehabilitation. There was an exponential increase in population coverage for Oral Health in the country, increasing from $9-43 \%$ between the years 2002 and 2016.[16, 17] However, there are several barriers hindering the continuation of this expansion and, above all, preventing it from being more equitable. The current government's political context, with an overwhelming ascendancy of the economic area over the social one, as well as the flagrant hostility towards any public policy that institutes or reaffirms social rights, completely eradicates the political conditions so that our Oral Health Policy, "Brasil Sorridente", can remain "possible".[17] Therefore, with reduced investments and the absence of a favorable political-institutional attitude, the guarantee of the citizens' constitutional right to have access to oral health services is at risk.

By taking on the task of evaluating the predictors of the demand for dental appointments in Primary Care Units with an Oral Health Team, this study aims to bring a contribution to oral health management, instrumentalizing the fight for the reduction of inequalities regarding the access to oral health in Brazil. Brazil. If the evaluation of such predictors is, in itself, an important pathway aimed at planning actions under any circumstances, it becomes essential in the current scenario.

This study showed that the demand for dental care is related to variables of individuals and also of the organization of oral health teams; additionally, it showed that only $56.9 \%$ of the users interviewed at these units seek the available dental care. Therefore, it is evident that despite the historical debt the Brazilian government has with its citizens regarding the offer of universal oral health services, the demand for these services - currently, finally offered to all age groups of the population - remains modest. There is an epidemiologically recorded accumulation of oral health needs in the country. For instance, the latest national oral health survey disclosed that $75.2 \%$ of the adult population (aged 35 to 44 years) needed dental care in Brazil.[18] However, the services offered at the PHC level are sought after, on average, by slightly more than $50 \%$ of the citizens of the territory.

As for individual predictors, our study indicated that the demand for dental care was significantly higher among women, when compared to men. The fact that men seek health services less frequently than women, even if they have serious health problems, is well established in the literature,[19, 20] and such behavior is attributed to cultural issues. Health risk behaviors are part of male culture values and the way men develop and experience their masculinity becomes one of the matrices of the ways one gets sick and dies. Thus, historically, from the point of view of common belief, men are strong beings, who hardly ever get sick, which means that the demand for health services, overall shows a female predominance.[20] Another central issue concerns the fact that women are still less valued in the labor market, having greater difficulty with employability, a fact that makes many of them become "housewives", that is, a homemaker who does not have a job outside the home and, therefore, has more available time in comparison to men to go to the Health Units, which in turn operate at times coinciding with the so-called "business" hours. Thus, regarding these "business" hours when the Health Units are open, also make it difficult for men to have access to health services. However, such differences in self-care patterns have important implications for future health outcomes, with the worsening of men's health conditions in relation to women with advancing age and the accumulation of problems that were not solved in a timely manner.[21]

The greater demand for dental care among black, brown and indigenous patients in comparison to white patients can be understood, as dental treatment needs also reflect racial inequalities, with worse indicators of oral health (caries, tooth loss, pain and need for prosthesis) being observed in the black and indigenous population.[8, 22] There is even an increase in the report of an intense or very intense degree of eating difficulties due to problems with teeth or dentures in the Brazilian population with black skin color.[8] In turn, our findings showed that the demand for dental care is greater among younger patients, a result that has been explained, since edentulism is a predominant condition among elderly Brazilians.[8] Maintaining the idea of dental care focused on tooth care discourages the elderly from performing oral health self-care.

Regarding the contextual predictors, considering the results found in our study, one can understand that the demand for care is directly related to a better interaction and the articulation of the oral health team with the other members of the Primary Care team and with the population of the assisted territory. In 2004, through the Brasil Sorridente program, a series of policies were implemented aiming at the expansion and qualification of oral health in PHC.[5, 7] The program highlights the importance of knowing the reality of the covered areas and the building of problem-solving and effective practices regarding the care offered by the $\mathrm{OHT}$.

The inclusion of the Oral Health Team in the Family Health Strategy, with joint planning and participation of the entire team to assist the population, with knowledge of the territory and being close to those assisted, brought as the directive the performance of actions in an integrated perspective of health prevention, promotion and provision of care.[23] However, despite all the attained advances, oral health access difficulties still persist in SUS. The challenges faced by the oral health teams are related to the comprehensive care, expansion and qualification of assistance, teamwork, planning, monitoring and evaluation of actions and working conditions.[7]

The reasons for the persistence of these difficulties can be identified when the results of our study show that the Oral Health Teams provide assistance, on average, to 1.2 PHC teams and the vast majority attend to individuals living outside the covered area on at least some days of the week. Such findings reflect the failure to match the number of OHTs affiliated to family health teams (FHTs) as recommended by the Brasil Sorridente guidelines. This situation becomes even more serious in the face of changes in the Brazilian political and economic framework in recent years. Constitutional Amendment number 95 of 2016 imposed a severe withdrawal of investments in oral health in SUS.[24] As an example, in 2018, the allocation of resources for oral health in SUS was 58.3\% less than the pre-implementation phase and the first year of PNSB implementation, when at that time, the country already had an institutional direction favoring the Oral Health Policy, although this was the period of least investment by the PNSB. The same Amendment, moreover, imposed a restriction on 
health and education expenses in the country for 20 years after its approval. Therefore, the prospects of reaching the ideal and desired proportion of one OHT for each FHT are, in the current context, unfeasible, although it has been proven necessary for equitable access to Oral Health and the changes in the epidemiological profile of the national population.

In the wake of the political-institutional decisions that Brazil made as of 2016, the new National Primary Care Policy (PNAB, Política Nacional de Atenção Básica) published in 2017 has disclosed, along with the spending ceiling, the neoliberal option - clearly focused on the viewpoint of health as a commodity and not as a right - which characterizes the federal government's actions. The new PNAB sees oral health as non-mandatory in the Family Health Strategy, which has already reflected in an increase in the number of municipalities that reduced the number of oral health teams in the Family Health Strategy.[5, 25] It is already possible to detect loss of implantation amplitude, indicated by the stabilization trend line regarding the number of these teams after January 2018. Between the 1st and the 21 st months of the publication of the PNAB 2017 Ordinance, a three-fold increase was observed regarding the number of municipalities that reduced the number of OHTs in the Family Health Strategy.[5] Obviously, the direct negative impact of this fact on citizens' access to oral health services should be more clearly perceived in the coming years.

The concept of Primary Health Care, the field in which the present investigation was developed, demonstrates that, in essence, PHC is aimed at caring for people, not diseases. Therefore, it has to be accessible, comprehensive, continuous and guarantee the coordination of care for cases that require referrals.[26, 27] This explains the fact that the present study has demonstrated that the user's chance to seek dental care is greater in OHTs that discuss cases and therapeutic projects. It is evident the need to rethink health work processes, changing the focus of attention, currently on the disease, so that it is focused on the individual and the community. This is not merely about improving the quality of care (albeit it is) but, above all, it is about the observance of Integrality in health, a fundamental SUS principle. After all, despite the many achievements and innovations achieved with PNSB since 2004, dental practices remain in the so-called 'westernized model' of modern dentistry (high technology and focus on treatment) and has been increasingly focusing on the provision of aesthetic treatments, largely motivated by profit and market reasons. Hence, it becomes necessary to redirect the approach when facing the global challenge imposed by oral diseases.[9]

This change, although necessary, is not an easy task, as it begins by recognizing the individual in their uniqueness, demands and needs, which requires 'expanding the clinic'.[28] In general terms, expanding the clinic means making the subject (patient) part of the decisions, recognizing their knowledge and interests, discussing the decisions with the entire health team and considering the contextual factors in which they are inserted without, however, disregarding technological advances, technical qualification and scientific evidence-based practice and practice as responsibility. This, in turn, is a responsibility to be shared daily with the team. In this new model, the cases must be discussed, the patients involved in the therapeutic decision-making and the work, therefore, must be centered on the individual. And once it is centered on the subject and their particular, unique, individual needs, this care - as a project to be developed, since it is not a ready recipe - is, then, characterized as a 'Singular Therapeutic Project'.[ 28]

It is evident, therefore, that it is a complex and challenging model, although it is undoubtedly a democratic one, as it involves the team and the patient. It is also a problem-solving one, as it does not disregard contextual factors known to be related to oral problems and, above all, it is equitable, as it considers the individual's interests and not only a list of previously indicated and standardized procedures. Thus, if it meets the individual's particular needs and conditions, it will obviously be better accepted by them and, consequently, it will be better evaluated and, as a result, more accessed.

From the perspective of overcoming the challenges that citizens meet to have access to dental care in the context of SUS, we point out the determining role of Community Health Agents (CHAs) regarding the relationship between the community and health services. The present investigation showed that the demand for dental appointments was significantly higher in OHTs that carry out actions articulated with other social facilities in the territory and that perform user embracement together with the Primary Care team. In the world, CHAs are seen as an important link to increase the access of communities to services, especially for people living in areas of greater vulnerability and, thus, to accelerate and sustain the progress in meeting health targets in Sustainable Development Goals (SDGs).[29, 30] However, a challenge for these professionals lies in the absence of a clear definition of their duties.[30]

In the Brazilian context, the CHA is considered a protagonist in the implementation of a practice that considers the expanded concept of health, essential in the implementation of SUS and the integration between PHC services with the community.[4, 31] However, the PNAB 2017 created the possibility of a Family Health Team without a CHA in its structure and also expanded the roles of these professionals.[25, 32] These new roles have been strongly questioned, as they are considered to be a mischaracterization of the CHA's work when prioritizing clinical activities.[4] The inclusion of tasks, especially those that distort the role of the $\mathrm{CHA}$ in creating a link between the community and the health team can, in addition to overburdening the $\mathrm{CHA}$ professional, negatively affect the quality of services and, in turn, the effectiveness of community programs that depend on them.[29]

We point out as possible limitations of this study its cross-sectional design, which does not allow the identification of causal relationships and the absence of questions related to behavior or about the needs perceived by users, variables that not collected in the PMAQ. Moreover, the interviews conducted at PMAQ did not address questions related to the behavior or the needs perceived by the users. In this sense, further research, particularly with a qualitative analysis, can contribute to the consolidation of scientific knowledge.

In turn, the strengths of this research comprise the sample size and distribution, which included participants from all over the national territory of a country known for its continental dimensions. Based on the findings of the present study, it was observed that it is necessary to strengthen oral health teams in the Unified Health System through public policies that direct their performance as initially established by the Brasil Sorridente program, as well as through devices with Singular Therapeutic Projects and discussion of clinical cases, implemented into practice to change the focus of care towards the integrality of health. Only through policies that reinforce the need for interaction and articulation of the oral health team with the other Primary Care members and with the territory will it be possible to act consistently and contribute to the improvement of the citizens' access to services and, consequently, to the staff epidemiological profile in oral health of the assisted population. Furthermore, it can be observed that the individual predictors reflect the oral health inequalities that still persist in the Brazilian population. These inequalities can be fought with greater investment in public oral health policies.

Page $12 / 15$ 


\section{Conclusion}

It is concluded that individual issues that do not favor the demand for oral health care, such as male gender, older age, and non-white ethnicity need to be considered both by the oral health team, as well as by the managers who organize and plan the services, since these profiles demand greater attention and active search to, in fact, guarantee equity in oral health access. In turn, oral health teams that effectively put the Brasil Sorridente guidelines into practice, that is, assist only one FHT, investigate the epidemiological profile of oral health in the population, discuss cases and therapeutic projects and articulate actions with other social facilities in the territory are most often sought after by the users.

\section{List Of Abbreviations}

AMAQ: Self-assessment for the Improvement of Access and Quality of Primary Care (Auto-avaliação para a Melhoria do Acesso e da Qualidade da Atenção Básica)

AMQ: Evaluation for Quality Improvement (Avaliação para Melhoria da Qualidade)

CHA: Community Health Agent

DS: Dental surgeon

FHS: Family Health Strategy

FHT: Family Health team

OHT: Oral Health team

PC: Primary Care

PHC: Primary Health Care

PMAQ-AB: National Program for Improving Access and Quality in Primary Care

PNAB: National Primary Care Policy (Política Nacional de Atenção Básica)

PNSB: National Oral Health Policy (Política Nacional de Saúde Bucal)

SDG: Sustainable Development Goals

TRIs: Teaching and Research Institutions

WHO: World Health Organization

\section{Declarations}

\section{Ethics approval and consent to participate}

The project was approved by an Ethics Committee on Research with Human Beings (CAAE 80477417.0.0000.0021). Participation was voluntary and confidential. Written informed consent was obtained from all participants. Data has been de-identified, and publicly available for free use on June $25,2019 . A l l$ protocols was carried out in accordance with the Helsinki Declaration.

\section{Consent for publication}

Not applicable.

\section{Availability of data and materials}

Data analysis has not yet been exhausted. For information on accessing the data, please contact the corresponding author.

\section{Competing interests}

The authors declare that they have no competing interests.

\section{Funding}

No funding was received for this study.

\section{Authors' contributions}

Estêvão de Azevedo Melo: Contributed to the study conception, design and drafting of the manuscript.

Livia Fernandes Probst: Contributed to the study conception, design, collection and interpretation of data and drafting of the manuscript. 
Luciane Miranda Guerra: Contributed to the study conception, design, and critically reviewed the manuscript.

Elaine Pereira da Silva Tagliaferro: Contributed to the study conception, design, and critically reviewed the manuscript.

Alessandro Diogo De-Carli: Contributed to the study conception, design, and critically reviewed the manuscript.

Antonio Carlos Pereira: Contributed to the study conception, design, and critically reviewed the manuscript.

All of the authors approved the final version to be published and agreed to be accountable for all aspects of the work, ensuring that questions related to the accuracy or integrity of any part of the work be appropriately investigated and resolved.

\section{Acknowledgements}

The research team would like to thank all users who agreed to participate in the PMAQ interview and gave their invaluable contribution to the planning in SUS. We would also like to thank the OHT professionals who were interviewed and who persist daily in their aim of building an equitable health system.

\section{References}

1. United Nations. General Assembly. Transforming our world: The 2030 agenda for sustainable development. 2015. doi:10.1007/s13398-014-0173-7.2.

2. WHO. World Health Organization. Adelaide Statement II on Health in All Policies. Adelaide: World Health Organization, Government of South Australia; 2017. https://www.who.int/phe/events/HiAP-conference-March2017/en/.

3. Brasil. Presidência da República. Constituição da República Federativa do Brasil de 1988. 1988. http://www.planalto.gov.br/ccivil_03/constituicao/constituicao.htm.

4. Almeida PF de, Medina MG, Fausto MCR, Giovanella L, Bousquat A, Mendonça MHM de. Coordenação do cuidado e Atenção Primária à Saúde no Sistema Único de Saúde. Saúde em Debate. 2018;42:244-60.

5. Lucena EHG de, Lucena CDRX de, Alemán JA de S, Pucca Júnior GA, Pereira AC, Cavalcanti YW. Monitoramento das equipes de saúde bucal após a Política Nacional de Atenção Básica 2017. Rev Saude Publica. 2020;54:99.

6. Viacava F, Oliveira RAD de, Carvalho CDC, Laguardia J, Bellido JG. SUS: oferta, acesso e utilização de serviços de saúde nos últimos 30 anos. Cien Saude Colet. 2018;23:1751-62.

7. Scherer $\mathrm{Cl}$, Scherer MD dos A. Advances and challenges in oral health after a decade of the "Smiling Brazil" Program. Rev Saude Publica. $2015 ; 49$.

8. Nico LS, Andrade SSC de A, Malta DC, Pucca Júnior GA, Peres MA. Saúde Bucal autorreferida da população adulta brasileira: resultados da Pesquisa Nacional de Saúde 2013. Cien Saude Colet. 2016;21:389-98.

9. Peres MA, Macpherson LMD, Weyant RJ, Daly B, Venturelli R, Mathur MR, et al. Oral diseases: a global public health challenge. Lancet. 2019;394:249-60.

10. Mittal R, Wong ML, Koh GC, Ong DLS, Lee YH, Tan MN, et al. Factors affecting dental service utilisation among older Singaporeans eligible for subsidized dental care - a qualitative study. BMC Public Health. 2019;19:1075.

11. Herkrath FJ, Vettore MV, Werneck GL. Utilisation of dental services by Brazilian adults in rural and urban areas: a multi-group structural equation analysis using the Andersen behavioural model. BMC Public Health. 2020;20:953.

12. Glick M, Williams DM, Kleinman D V., Vujicic M, Watt RG, Weyant RJ. A new definition for oral health developed by the FDI World Dental Federation opens the door to a universal definition of oral health. Br Dent J. 2016;221:792-3.

13. von Elm E, Altman DG, Egger M, Pocock SJ, Gøtzsche PC, Vandenbroucke JP. The Strengthening the Reporting of Observational Studies in Epidemiology (STROBE) statement: guidelines for reporting observational studies. J Clin Epidemiol. 2008;61:344-9.

14. Brasil. Ministério da Saúde. Instrumento de avaliação externa do saúde mais perto de você - acesso e qualidade. Programa Nacional de Melhoria do Acesso e da Qualidade da Atenção Básica (PMAQ). 2017. http://189.28.128.100/dab/docs/portaldab/documentos/instrumento_amaq_ab_sb_3ciclo.pdf.

15. R Core Team. A language and environment for statistical computing. 2020;4:2020-1.

16. Pucca Jr GA, Gabriel M, De Araujo MED, De Almeida FCS. Ten years of a national oral health policy in Brazil: Innovation, boldness, and numerous challenges. J Dent Res. 2015;94:1333-7.

17. Narvai PC. Ocaso do 'Brasil Sorridente' e perspectivas da Política Nacional de Saúde Bucal em meados do século XXI. Tempus Actas de Saúde Coletiva. 2020;14:175-87.

18. Brasil. Ministério da Saúde. Projeto SBBrasil 2010: Pesquisa Nacional de Saúde Bucal - Resultados Principais. Brasília, DF; 2011. http://bvsms.saude.gov.br/bvs/publicacoes/SBBrasil_2010.pdf.

19. Bidmon S, Terlutter R. Gender Differences in Searching for Health Information on the Internet and the Virtual Patient-Physician Relationship in Germany: Exploratory Results on How Men and Women Differ and Why. J Med Internet Res. 2015;17:e156.

20. Levorato CD, Mello LM de, Silva AS da, Nunes AA. Fatores associados à procura por serviços de saúde numa perspectiva relacional de gênero. Cien Saude Colet. 2014;19:1263-74.

21. Schlichthorst M, Sanci LA, Pirkis J, Spittal MJ, Hocking JS. Why do men go to the doctor? Socio-demographic and lifestyle factors associated with healthcare utilisation among a cohort of Australian men. BMC Public Health. 2016;16:1028.

22. Guiotoku SK, Moysés ST, Moysés SJ, França BHS, Bisinelli JC. Iniquidades raciais em saúde bucal no Brasil. Rev Panam Salud Pública. $2012 ; 31: 135-41$.

23. Brasil. Ministério da Saúde. Secretaria de Atenção à Saúde. Departamento de Atenção Básica. Cadernos de Atenção Básica n 17 - Saúde Bucal. 2008. http://bvsms.saude.gov.br/bvs/publicacoes/saude_bucal.pdf.

Page $14 / 15$ 
24. Brasil. Emenda Constitucional no 95 de 15 de dezembro de 2016. Altera o Ato das Disposições Constitucionais Transitórias, para instituir o Novo Regime Fiscal, e dá outras providências. Diário Oficial da União. 2016. http://www.planalto.gov.br/ccivil_03/constituicao/emendas/emc/emc95.htm.

25. Brasil. Ministério da Saúde. Portaria $n^{\circ}$ 2.436, de 21 de setembro de 2017. Aprova a Política Nacional de Atenção Básica, estabelecendo a revisão de diretrizes para a organização da Atenção Básica, no âmbito do Sistema Único de Saúde (SUS). 2017.

https://bvsms.saude.gov.br/bvs/saudelegis/gm/2017/prt2436_22_09_2017.html.

26. Petersen PE. Strengthening of Oral Health Systems: Oral Health through Primary Health Care. Med Princ Pract. 2014;23:3-9.

27. Starfield B. Is Patient-Centered Care the Same As Person-Focused Care? Perm J. 2011;15:63-9.

28. Campos GW de S, Figueiredo MD, Pereira Júnior N, Castro CP de. A aplicação da metodologia Paideia no apoio institucional, no apoio matricial e na clínica ampliada. Interface - Comun Saúde, Educ. 2014;18 suppl 1:983-95.

29. Jaskiewicz W, Tulenko K. Increasing community health worker productivity and effectiveness: a review of the influence of the work environment. Hum Resour Health. 2012;10:38.

30. Cometto G, Ford N, Pfaffman-Zambruni J, AkI EA, Lehmann U, McPake B, et al. Health policy and system support to optimise community health worker programmes: an abridged WHO guideline. Lancet Glob Heal. 2018;6:e1397-404.

31. Samudio JLP, Brant LC, Martins AC de FDC, Vieira MA, Sampaio CA. Agentes comunitários de saúde na atenção primária no brasil: multiplicidade de atividades e fragilização da formação. Trab Educ e Saúde. 2017;15:745-69.

32. de Almeida ER, de Sousa ANA, Brandão CC, de Carvalho FFB, Tavares G, Silva KC. Política Nacional de Atenção Básica no Brasil: uma análise do processo de revisão (2015-2017). Rev Panam Salud Pública. 2018;42:1-8.

\section{Supplementary Files}

This is a list of supplementary files associated with this preprint. Click to download.

- SuppMaterialBMCPublicHealth.docx 